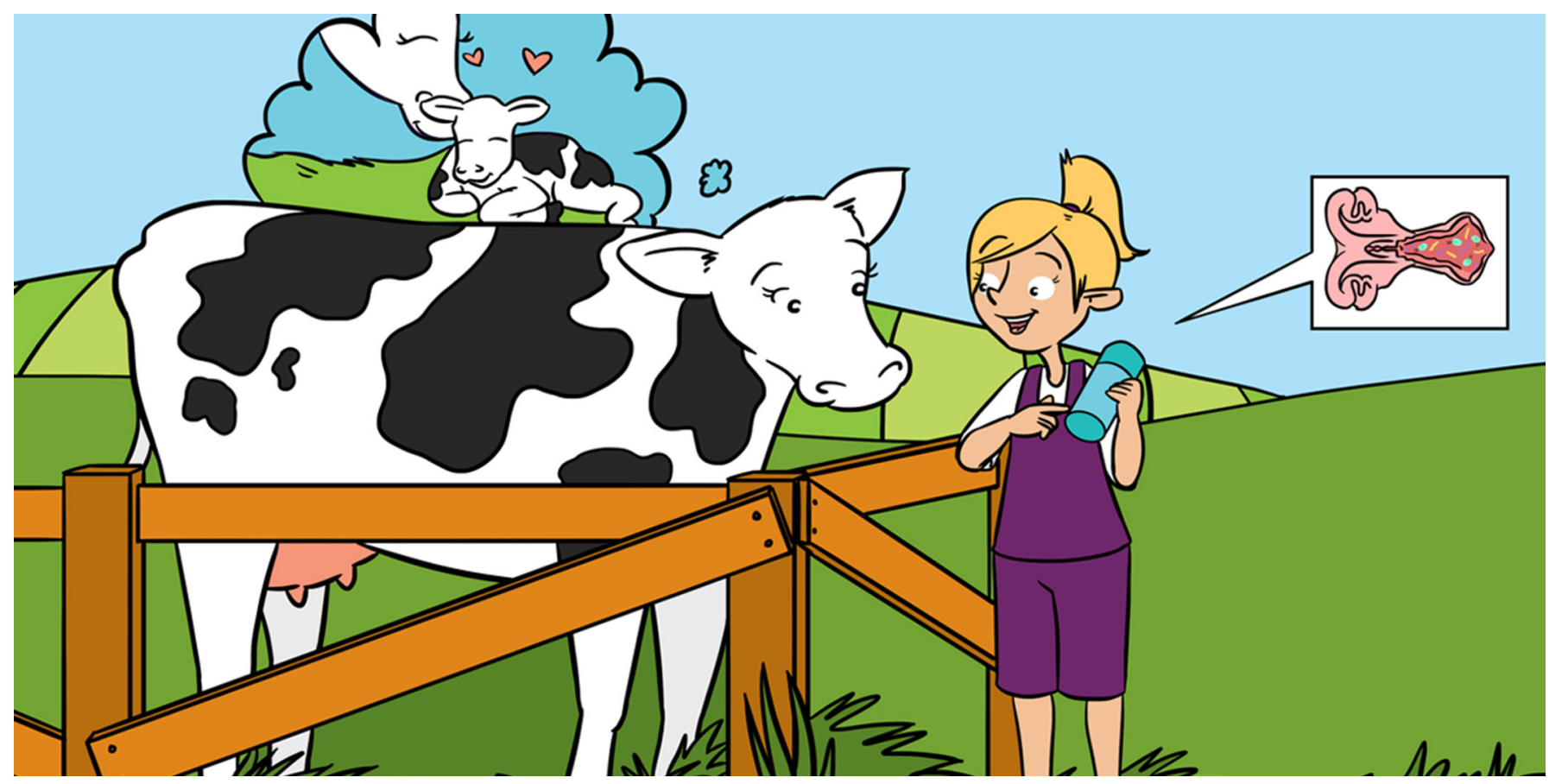

\title{
BACTERIA IN THE REPRODUCTIVE TRACT: THEY ARE NOT ALL BAD!
}

Taylor B. Seay, Brooke A. Clemmons, Phillip R. Myer * and Kyle J. McLean *

Department of Animal Science, University of Tennessee, Knoxville, TN, United States

YOUNG REVIEWERS:

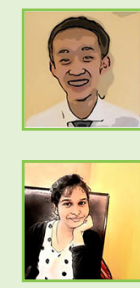

ETHAN

AGE: 14

NETTRA

AGE: 16
Bacteria in the reproductive tract were previously thought to be "bad" and it was believed that they decreased the chances of successful pregnancies. However, healthy bacteria have been found in the reproductive tracts of humans and cattle! These "good" bacteria help maintain a healthy reproductive tract by reducing the ability of "bad" bacteria to grow, helping immune cells to function properly, and maintaining an appropriate $\mathrm{pH}$ in the environment. Researchers have found that differences in the bacterial communities of the uterus can influence whether cattle get pregnant and give birth to healthy calves. Future studies may evaluate how we can modify these bacterial communities to create the best environment in the reproductive tract for better reproductive success.

\section{INTRODUCTION}

The world population is quickly increasing, from 7.7 billion people today to an estimated 10 billion people within the next 30 years. This growing number of people leads to an increase in the amount 


\section{PATHOGEN}

A microorganism that is commonly harmful and can cause disease.

\section{FEMALE}

REPRODUCTIVE

TRACT

Organ system that functions to produce new offspring in females. Consists of the vagina, cervix, uterus, oviduct, and ovaries.

\section{BACTERIAL}

\section{DIVERSITY}

Measurement of the number of different bacterial species and how genetically different the bacteria are in a sample. A sample with a higher number of different species has a greater diversity. of food needed to feed everyone. The agricultural and livestock industries are very important to the food supply and they are faced with the challenge of producing enough food with limited resources. To overcome this challenge, scientists are evaluating factors that can affect food production. Animal science researchers are evaluating the bacterial communities in the reproductive tract and their role in the successful reproduction of animals that contribute to the food supply.

Bacteria are commonly thought to be "bad," due to the many types of pathogenic bacteria that can cause various illnesses. However, there are also "good" bacteria present in the environment and the bodies of humans and animals, which help to maintain healthy and productive bodies! Helpful bacteria are found in many organs of the body, with most of them located in the digestive tract. These gastrointestinal bacteria help to break down the foods humans and animals eat. The products that bacteria produce from digesting foods can be used by humans or animals for growth or for maintaining normal body functions. The importance of bacteria in the digestive tract led scientists to explore bacteria in other body parts, such as the reproductive tract, and to ask how these bacteria may influence reproductive health and breeding success.

\section{ARE THERE HEALTHY BACTERIA IN THE REPRODUCTIVE TRACT?}

Many years ago, scientists believed that the female reproductive tract did not contain any bacteria unless there was an infection present. The presence of bacteria in the reproductive tract, especially during pregnancy, was thought to be bad for fetal growth and the health of the uterus. However, as scientists developed new technologies to detect and identify more bacteria, they found that there is a community of healthy bacteria in the reproductive tract!

In humans, there is a very low bacterial diversity of bacteria in the healthy reproductive tract. The low diversity is due to a single genus, named Lactobacillus, accounting for the majority of the reproductive tract bacteria. The bacterial communities of the reproductive tract in cattle, however, are very different from humans in this respect. There is high bacterial diversity in the cattle reproductive tract, meaning there are many different types and species of bacteria present. The bacteria in the cow vagina are more diverse than that of the uterus, with many bacteria that are similar to those found in the gastrointestinal tract (Figure 1). The high diversity of bacteria in the vagina and the similarities to gastrointestinal tract bacteria are believed to be due to the opening of the vagina to the external environment, which allows bacteria to enter and grow, while the uterus is more internal, with limited access to external bacteria sources [1]. 
Figure 1

The cow vagina has a greater number of bacteria, and a greater bacterial diversity, than the uterus. Some bacterial species are shared between the uterus and vagina, but in different abundances (Image created using BioRender).

\section{METABOLISM}

Chemical reactions that breakdown substances, such as food, into other molecules needed for normal body functions.

\section{LACTIC ACID}

A chemical formed when sugars are broken down for energy in the absence of oxygen. Lactic acid is produced by the metabolism of several bacterial species.

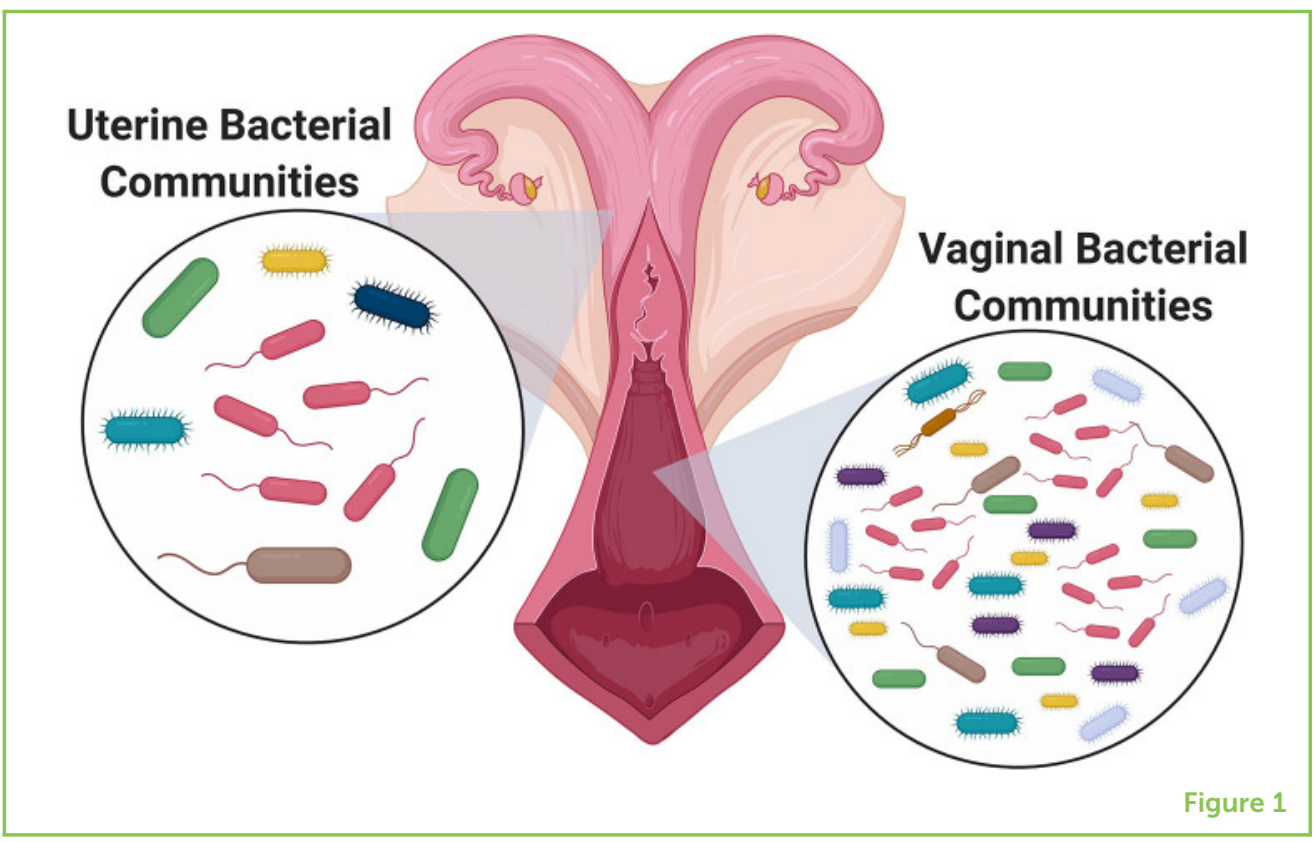

\section{HOW DO BACTERIA HELP KEEP THE REPRODUCTIVE TRACT} HEALTHY?

Just like humans and animals, bacteria must consume "food" that supplies them with energy and nutrients to survive. The process of converting food to energy and nutrients is called metabolism. Metabolism includes reactions that occur inside cells to produce many different molecules and compounds necessary for the functions that keep us-and bacteria-alive. Bacteria can consume "food" in the form of various substances that are produced by the cells of their host's reproductive tract or that enter the reproductive tract from the bloodstream. The bacteria consume these substances to create energy and other molecules that allow them to survive and function. Bacteria release other products of metabolism that they do not need, which can help support functions of the host, including maintaining a healthy reproductive tract (Figure 2).

The products that bacteria release into their environments help to maintain a healthy reproductive tract by supporting healthy bacterial communities, inhibiting pathogen growth, maintaining the proper acidity of the environment, and helping the cells of the immune system to function properly. For example, Lactobacillus species of bacteria help to keep the human reproductive tract healthy by metabolizing the sugar glucose to produce energy and lactic acid. The bacteria use the energy for their survival, while the lactic acid is released into their environment. The lactic acid released lowers the $\mathrm{pH}$ of the reproductive tract, making the environment more acidic, which prevents pathogenic bacteria from growing [2]. Lactobacillus species have been shown to be in low abundance in the cattle reproductive tract [3], however, other bacteria are present that can perform similar functions. Additional types of bacteria can 
Figure 2

Bacteria contribute to a healthy environment in the reproductive tract by taking in molecules and breaking them down through metabolic processes. Bacteria's metabolism provides them with the components they need to survive. Other components are released into the surrounding environment, such as that of the reproductive tract. These products can benefit the reproductive tract environment by supporting the functions of other bacteria, adjusting the $\mathrm{pH}$ of the environment, and regulating the functions of immune cells (Image created using BioRender).

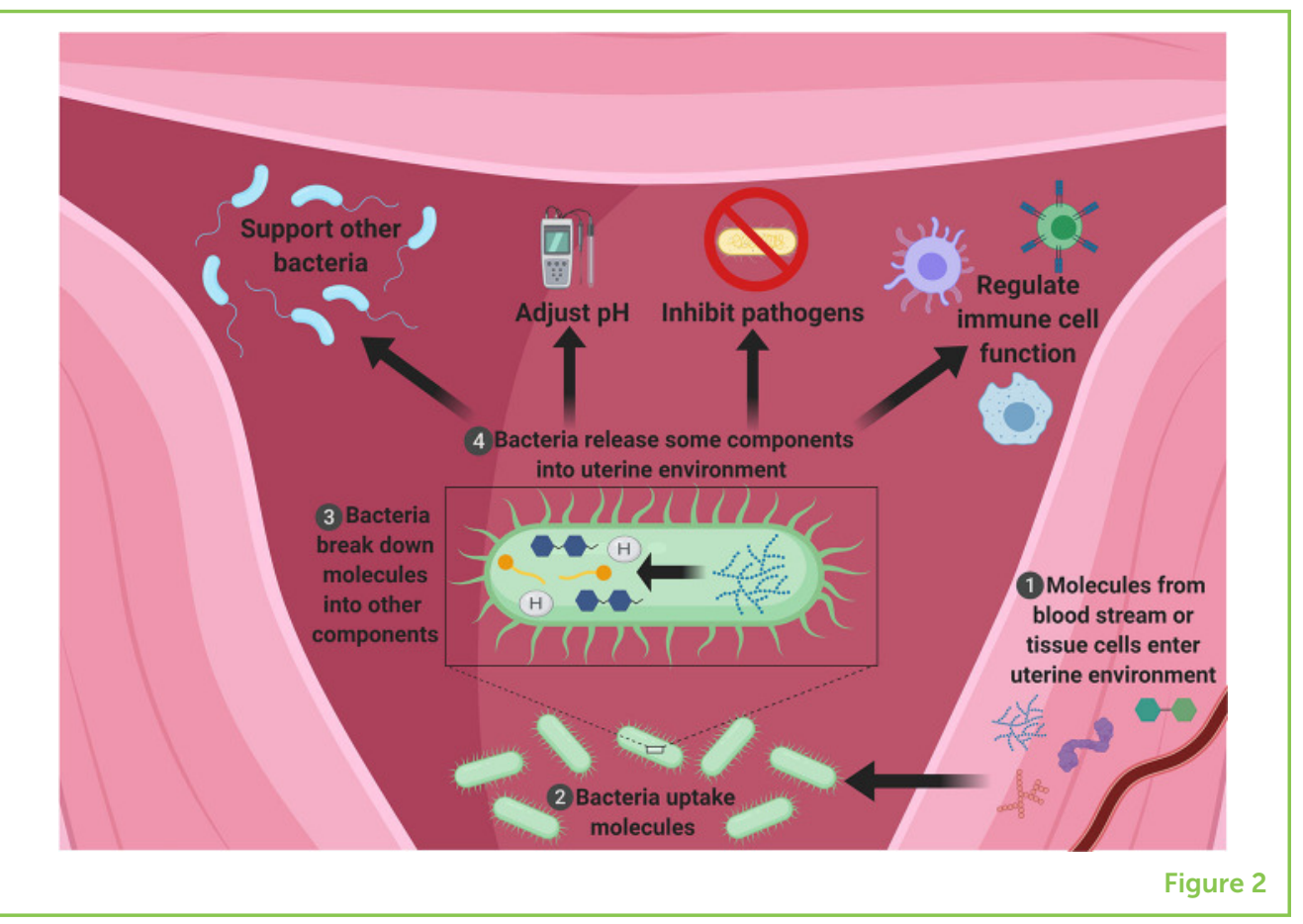

produce products that regulate the activity of the immune cells. These immunes can help an animal fight off pathogens or create an environment in the uterus that helps support pregnancy development. Good bacteria can also inhibit the growth of pathogenic bacteria by producing anti-bacterial compounds, or by out-competing pathogens by consuming the resources those pathogens need to grow. All these functions of bacteria in the reproductive tract are necessary for a healthy environment that can allow for a pregnancy to develop.

\section{HOW ARE BACTERIA IN THE REPRODUCTIVE TRACT RELATED TO SUCCESSFUL BREEDING AND PREGNANCY?}

As the agricultural industry is trying to produce more efficient cattle to feed the growing world population, it is important to have cows become pregnant as easily and quickly as possible. However, if the bacterial communities in the reproductive tract are altered, creating an unfavorable environment for pregnancy, the cow may not be able to get pregnant or produce a healthy calf (Figure 3). The majority of previous research evaluated pathogenic bacteria and how they reduce the ability of an animal to become pregnant. It is known that cows are more likely to have infections and high abundance of pathogenic bacteria in the uterus after giving birth to a calf, which leads to difficulty when trying to breed the cow again. However, recent research has begun to evaluate the relationship between the healthy bacterial communities in the reproductive tract and an animal's ability to establish a successful pregnancy. 
Figure 3

Bacterial communities present in the uterus prior to breeding can affect reproductive outcomes. (A) Cows with balanced bacterial communities in the uterus have a better chance of getting pregnant and producing offspring. These cows have more healthy bacteria (green) that contribute to a better uterine environment. Pathogenic bacteria (red) can be present in healthy animals at low abundances. (B) Cows with altered bacterial communities in the uterus are less likely to become pregnant. These cows have a greater abundance of pathogenic bacteria (without infection) in the uterine environment, which does not support pregnancy development (Image created using BioRender).

\section{PROBIOTICS}

Live bacteria that can be added to an environment for health benefits. Probiotics can alter the bacteria present in the community and change the metabolic products that are released.

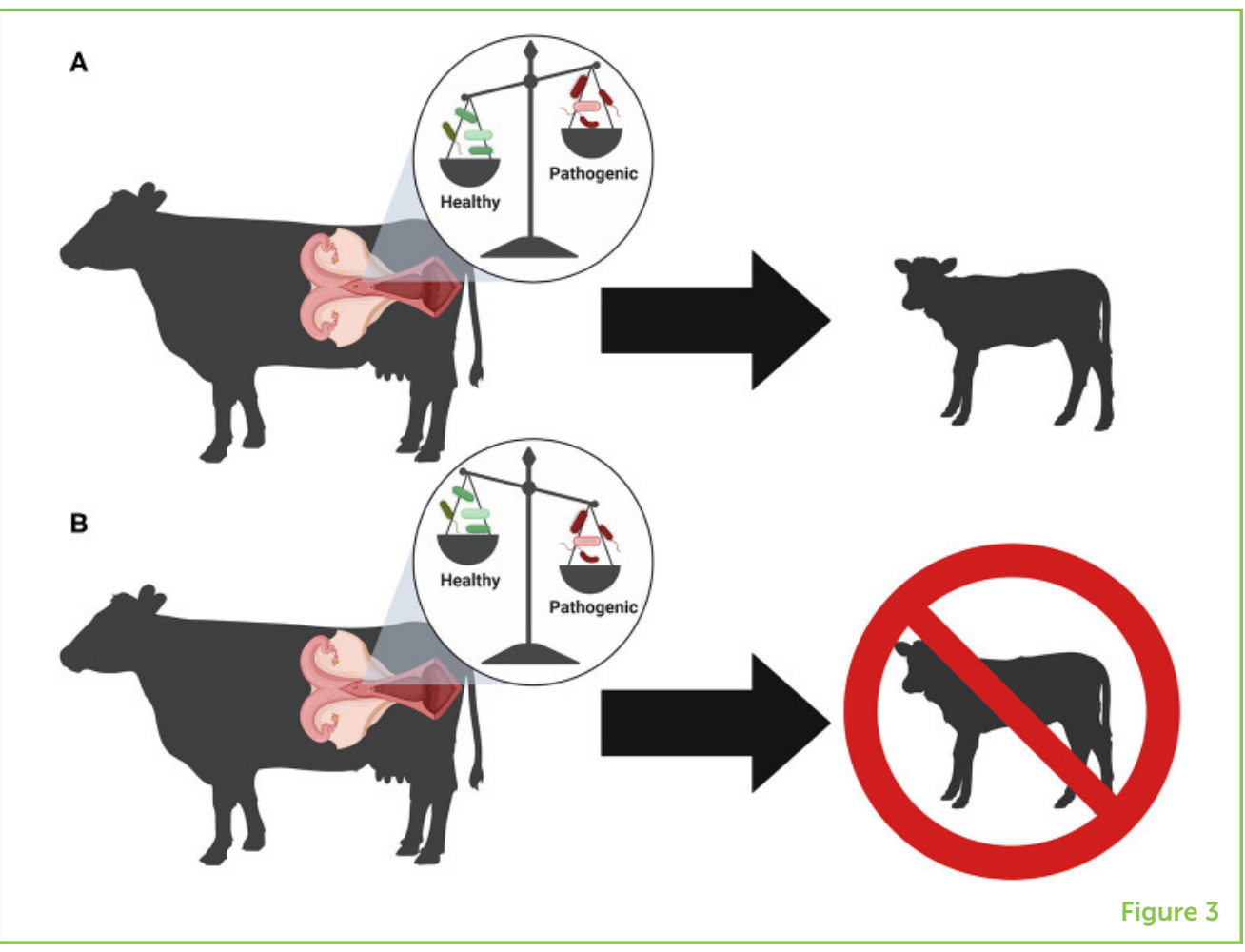

Scientists evaluated bacterial communities in the reproductive tracts of cows prior to breeding, to determine whether bacteria were related to pregnancy outcomes. Cows that became pregnant had a distinctly different composition of bacterial communities in the uterus prior to breeding in the uterus than cows that did not become pregnant. Specifically, cows that did not become pregnant had more pathogenic bacteria, although no infection was present [4]. These data suggest that differences in uterine bacterial communities can influence a cow's reproductive success (Figure 3). The ability of bacteria to influence reproductive success is likely due to their effects on the reproductive tract environment, by controlling factors that are important for pregnancy development. Further studies will evaluate the role of the uterine bacteria during pregnancy and how they may impact fetal growth, health, and development.

\section{HOW CAN WE IMPROVE BREEDING SUCCESS WITH REPRODUCTIVE TRACT BACTERIA?}

Since a cow's bacterial communities have proven to influence the reproductive tract environment and pregnancy development, studies are also evaluating methods to modify the composition of the bacterial communities. By altering the kinds of bacteria present in these communities, we could potentially create a healthy reproductive tract environment that is the best for supporting pregnancy. Studies have tested probiotics for this purpose. Probiotics are live bacteria, such as Lactobacillus, that are known to have health benefits for the host. 
Probiotics can be added to the reproductive tract and contribute to the animal's reproductive environment. Although Lactobacillus has a naturally low abundance in the reproductive tract of cattle, scientists have begun to test the use of Lactobacillus as a probiotic in cows. Results have been positive for treating infections, controlling immune system responses, and improving the number of animals that become pregnant [5]. Further studies are needed to evaluate the use of probiotics in breeding when infection is not present, to see how probiotics regulate the normal balance of bacterial communities in cattle.

\section{CONCLUSION}

Bacteria are not all bad, as there are many different types of bacteria that perform important functions to benefit the host. Bacterial communities are essential to the host's health and performance, due to their contributions to the various environments throughout the body. Although the reproductive tract was once believed to be bacteria-free, research has now uncovered the importance of healthy bacteria in reproductive health and success. There are many diverse bacteria, including Lactobacillus, that live in the reproductive tracts of cattle and benefit the reproductive tract environment. Lactobacillus is well-understood for its function in the reproductive tract and has been the most studied regarding probiotics in the reproductive tracts of cattle and humans. Further studies are needed to determine how and if other bacteria can be used as probiotics. As we come to further understand the roles of bacteria in the reproductive tract, we may be able to use these good bacteria to improve breeding outcomes, which would help to produce more cattle to feed the ever-increasing population of the world.

\section{REFERENCES}

1. Clemmons, B. A., Reese, S. T., Dantas, F. G., Franco, G. A., Smith, T. P. L., Adeyosoye, O. I., et al. 2017. Vaginal and uterine bacterial communities in postpartum lactating cows. Front. Microbiol. 8:1047. doi: 10.3389/fmicb. 2017.01047

2. Ronnqvist, D. J., Forsgren-Brusk, B., and Grahn-Hkansson, E. 2006. Lactobacilli in the female genital tract in relation to other genital microbes and vaginal $\mathrm{pH}$. Acta Obstet. Gynecol. Scand. 85:726-35. doi: 10.1080/00016340600578357

3. Swartz, J. D., Lachman, M., Westveer, K., O'Neill, T., Geary, T., Kott, R. W., et al. 2014. Characterization of the vaginal microbiota of ewes and cows reveals a unique microbiota with low levels of Lactobacilli and near-neutral pH. Front. Vet. Sci. 1:19. doi: 10.3389/fvets.2014.00019

4. Ault, T. B., Clemmons, B. A., Reese, S. T., Dantas, F. G., Franco, G. A., Smith, T. P. L., et al. 2019. Bacterial taxonomic composition of the postpartum cow uterus and vagina prior to artificial insemination. J. Anim. Sci. 97:4305-13. doi: 10.1093/jas/skz212 
5. Peter, S., Gärtner, M. A., Michel, G., Ibrahim, M., Klopfleisch, R., Lübke-Becker, A., et al. 2018. Influence of intrauterine administration of Lactobacillus buchneri on reproductive performance and pro-inflammatory endometrial mRNA expression of cows with subclinical endometritis. Sci. Rep. 8:5473. doi: 10.1038/s41598-018 $-22856-y$

SUBMITTED: 14 July 2020; ACCEPTED: 01 February 2021;

PUBLISHED ONLINE: 25 February 2021.

EDITED BY: Viduranga Y. Waisundara, Australian College of Business and Technology-Kandy Campus, Sri Lanka

CITATION: Seay TB, Clemmons BA, Myer PR and McLean KJ (2021) Bacteria in the Reproductive Tract: They Are Not All Bad! Front. Young Minds 9:550269. doi: 10. 3389/frym.2021.550269

CONFLICT OF INTEREST: The authors declare that the research was conducted in the absence of any commercial or financial relationships that could be construed as a potential conflict of interest.

COPYRIGHT @ 2021 Seay, Clemmons, Myer and McLean. This is an open-access article distributed under the terms of the Creative Commons Attribution License (CC BY). The use, distribution or reproduction in other forums is permitted, provided the original author(s) and the copyright owner(s) are credited and that the original publication in this journal is cited, in accordance with accepted academic practice. No use, distribution or reproduction is permitted which does not comply with these terms.

\section{YOUNG REVIEWERS}

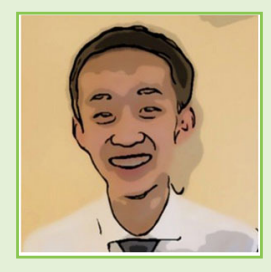

\section{ETHAN, AGE: 14}

Hi! My name is Ethan. At my regional science fair, I won Best Junior Project, Best Biology Project, Gold Medal, and a qualification to the Canada-Wide Science Fair, where I achieved a bronze medal. I have also been a finalist at the InspoScience Canada IRIC. Besides, I enjoy debating, having won the title of national champion and second speaker this past year, and public speaking. I am an avid writer, being published for my poems, short stories, and argumentative articles.

\section{NETTRA, AGE: 16}

She is a young scholar studying second year Higher Secondary schooling. Her fascination with Biology began to develop at a young age, led her to conduct simple experiments at home and shows keen interest in molecular biology. Inspired by her doctor parents, she set her goal to become a doctor (ophthalmologist) herself and serve the scientific community. Her dream is to explore underwater creatures by snorkeling the Great Barrier Reef. She reads more of scientific fictions and spends her spare time with baking cakes and cookies. 

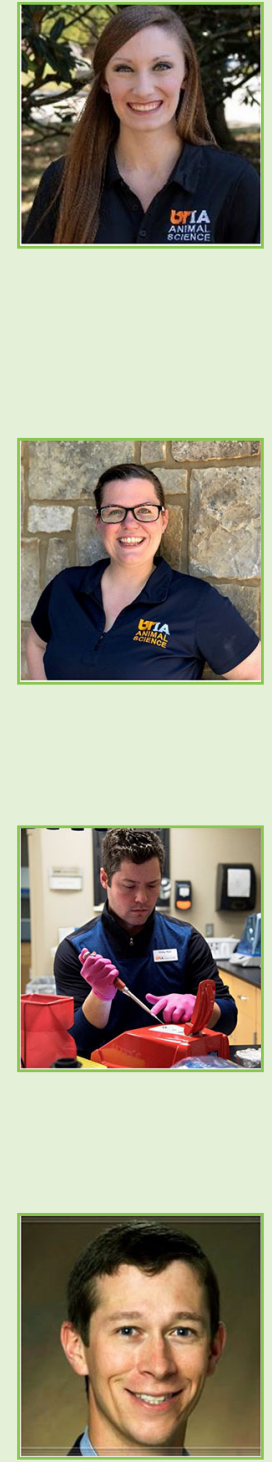

\section{AUTHORS}

\section{TAYLOR B. SEAY}

Taylor B. Seay grew up in East Tennessee with a passion for working with animals. She received her bachelor's and master's degrees from the University of Tennessee-Knoxville Department of Animal Science, where she is currently a Ph.D. student and Graduate Research Assistant. Her research focuses on evaluating the reproductive tract and rumen bacterial communities of beef heifers. She is interested in the factors affecting these microorganisms and how they can influence reproductive efficiency in beef cattle.

\section{BROOKE A. CLEMMONS}

Brooke A. Clemmons is Ph.D. student in Animal Science in Knoxville, TN. She grew up in cities, but always loved farm animals. Brooke currently works with cattle to understand how different environmental factors affect how cows use food. She specifically focuses on how different things, like pregnancy and genetics, affect the microbes that live in the guts of cows, and how we can use those to make animals grow better and healthier.

\section{PHILLIP R. MYER}

Phillip R. Myer is an Assistant Professor at the University of Tennessee Department of Animal Science. He is interested in how microbes in beef cattle impact feed efficiency. Phillip is also interested in how beef cattle can interact with their microbes. His research group uses DNA technologies to help investigate these interactions. He hopes his research can help inform, improve, and be part of the solution to future global protein and food demand. *pmyer@utk.edu

\section{KYLE J. MCLEAN}

Kyle J. McLean grew up in southeastern Montana where he developed a passion for science and animals. He received an Associate's of Science degree at Eastern Wyoming College. Then, he went to Stillwater, OK where he received a Bachelor of Science and Master of Science degrees from Oklahoma State University. Finally, Dr. McLean received a Ph.D. in Animal Science from North Dakota State University. Upon graduation, he spent 2 years as a post-doctoral research associate at the University of Kentucky before coming to the University of Tennessee where he is conducting research in cattle reproduction. *kmclea10@utk.edu 